\title{
Sintesis Nanopartikel Perak Menggunakan Ekstrak Daun Kluwak Pangium edule Reinw Sebagai Bioreduktor dan Uji Aktivitasnya Sebagai Antioksidan
}

\author{
Indrawati Patabang ${ }^{1}$, Syahruddin Kasim ${ }^{1}$, Paulina Taba ${ }^{1}$ \\ ${ }^{I}$ Departemen Kimia, Fakultas Matematika dan Ilmu Pengetahuan Alam \\ Universitas Hasanuddin \\ E-mail: kasimsyahruddin@gmail.com
}

\begin{abstract}
Silver nanoparticles have been synthesized using kluwak leaf extract (Pangium edule Reinw) as bioreductor and antioxidant activity assay. The nanoparticles formed were monitored by observing UV-Vis absorption and characterized by using FTIR, PSA, $X R D$ and SEM instruments. The result of functional group characterization with FTIR show that the functional groups $\mathrm{OH}, \mathrm{C}=\mathrm{O}, \mathrm{C}-\mathrm{O}$ and $\mathrm{CH}_{2}$ act as $\mathrm{Ag}^{+}$reducing agent. The size of silver nanoparticles was determined by using Particle Size Analyzer (PSA) and the result show average particle size distribution of $93.2 \mathrm{~nm}$. Morphology of AgNp were observed by Scanning Electron Microscope (SEM) and X-Ray Difraction (XRD) analysis show result of $51,78 \mathrm{~nm}$. The antioxidant activity was shown by in kluwak leaf extract and silver nanoparticles with IC50 values respectively 831,33 ppm dan 1493,09 ppm.
\end{abstract}

Kata kunci: Characterization, Reduction Method, Silver Nanoparticles

\section{PENDAHULUAN}

Perkembangan nanoteknologi sekarang ini sangat pesat karena memiliki peranan penting pada berbagai bidang. Nanoteknologi secara umum dapat didefinisikan sebagai teknologi perancangan (desain), pembuatan dan aplikasi struktur atau material yang berdimensi nanometer. Salah satu penerapan nanoteknologi saat ini adalah preparasi material yang berukuran 1-100 nm (nanopartikel). Nanopartikel memiliki sifat kimia dan fisika yang lebih unggul dibandingkan partikel yang berukuran besar. Nanopartikel memiliki banyak kegunaan seperti dalam bidang sains, teknologi, industri dan kesehatan. Nanopartikel yang menarik dikembangkan adalah nanopartikel perak (Ariyanta, 2014; (Nagarajan dan Hotton, 2008). Secara garis besar sintesis nanopartikel perak dapat dilakukan dengan menggunakan metode top down (fisika) dan bottom up (kimia). Namun, metode ini memiliki kekurangan seperti penggunaan bahan kimia yang berlebihan, pencemaran lingkungan, dan biaya yang mahal (Asri, 2015). Teknik lain yang digunakan dalam memproduksi nanopartikel perak adalah metode reduksi kimia, fotokimia, sonokimia dan lain-lain. Metode reduksi kimia sering digunakan karena prosesnya mudah, biaya relatif murah serta kemungkinan hasil diproduksi dalam skala besar (Wahyudin dkk., 2011). Penggunaan ekstrak tumbuhan untuk sintesis nanopartikel perak menguntungkan karena bahan mudah didapat dan nontoksik, bahan kimia yang digunakan relatif kurang dan beragam metabolit sekunder dapat digunakan sebagai bioreduktor nanopartikel perak. Ekstrak tumbuhan yang dapat 
digunakan sebagai bioreduktor yaitu tumbuhan yang memiliki senyawa yang dapat berperan sebagai agen pereduksi ion $\mathrm{Ag}^{+}$dalam larutan menjadi $\mathrm{Ag}^{0}$ (Isaac dkk., 2013). Senyawa yang terdapat pada tumbuhan dan dapat berfungsi sebagai agen pereduksi adalah terpenoid, fenolik, flavonoid, tanin, steroid, saponin, alkaloid dan lain-lain (Matutu dkk., 2016). Nanopartikel dapat dikembangkan dalam bidang kesehatan sebagai antioksidan. Antioksidan adalah senyawa kimia yang dapat menunda, memperlambat dan mencegah terjadinya proses oksidasi dengan mengikat radikal bebas (Rumengan dan Mantiri, 2015). Proses tersebut dapat mencegah pembentukan radikal dan molekul yang sangat reaktif (Winarsi, 2007). Beberapa penelitian yang berhubungan dengan sintesis nanopartikel perak telah dilakukan dengan menggunakan ekstrak tumbuhan dan aktivitasnya diuji sebagai antioksidan. AbdelAziz dkk (2015) mensintesis nanopartikel perak dengan menggunakan buah kozan muda sebagai bioreduktor dan memperoleh nanopartikel perak dengan ukuran sebesar 30-50 nm dan nanopartikel perak yang diperoleh memiliki nilai IC $_{50}$ sebagai antioksidan sebesar 13.720 ppm dan ekstrak sampel sebesar 12.630 ppm. Thomas dkk (2018) mensintesis nanopartikel perak dengan menggunakan ekstrak tumbuhan Coleus Vettiveroids sebagai bioreduktor, dimana diameter nanopartikel perak yang diperoleh adalah $5 \mathrm{~nm}$ serta nilai $\mathrm{IC}_{50}$ yang diperoleh dari nanopartikel perak adalah 719,01 ppm. Bharathi dkk (2018) mensintesis nanopartikel perak menggunakan ekstrak kulit batang Diospyros Montana sebagai bioreduktor. Nanopartikel perak yang terbentuk memiliki diameter rata-rata sebesar $28 \mathrm{~nm}$ dengan aktivitas antioksidan $89,12 \%$.

\section{METODE PENELITIAN}

\section{Preparasi dan Pembuatan Ekstrak Daun Kluwak}

Tumbuhan yang digunakan dalam penelitian ini yaitu daun kluwak (Pangium edule Reinw). Daun kluwak (Pangium edule Reinw) yang telah dikeringkan dan dicuci bersi, dihaluskan kemudian ditimbang sebanyak 5 gram, dimasukkan ke dalam gelas kimia $200 \mathrm{~mL}$ dan ditambahkan $100 \mathrm{~mL}$ akuabides lalu dipanaskan hingga mendidih kemudian didinginkan. Setelah mencapai suhu ruang air rebusan disaring menggunakan kertas saring whatman no. 42. Sebagian filtrat dianalisis menggunakan FTIR dan selebihnya digunakan dalam sintesis nanopartikel perak.

\section{Pembuatan Larutan $\mathrm{AgNO}_{3}$ Variasi Konsentrasi 2 mM, 1,5 mM, 1 mM dan 0,5 Mm}

Sebanyak 0,068 gram serbuk $\mathrm{AgNO}_{3}$ dilarutkan ke dalam akuabides hingga volume $200 \mathrm{~mL}$ dan dicampur sampai homogen untuk membuat larutan $\mathrm{AgNO}_{3} 2 \mathrm{mM}$. Selanjutnya larutan diambil sebanyak 37,5 mL, $25 \mathrm{~mL}$ dan 12,5 mL, dimasukkan ke dalam labu ukur $50 \mathrm{~mL}$ dan ditambahkan akuabides hingga tanda batas untuk membuat konsentrasi $\mathrm{AgNO}_{3} 1,5 \mathrm{mM} ; 1 \mathrm{mM}$ dan 0,5 mM.

\section{Biosintesis Nanopartikel Perak}

Dalam penelitian ini, sintesis nanopartikel perak dilakukan dengan mencampur larutan $\mathrm{AgNO}_{3}$ dengan ekstrak daun kluwak. Kemudian dilakukan penentuan konsentrasi optimum larutan $\mathrm{AgNO}_{3}$ dalam pembentukan nanopartikel perak yang akan digunakan untuk proses sintesis nanopartikel selanjutnya. Penentuan konsentrasi optimum dari $\mathrm{AgNO}_{3}$ dilakukan dengan mencampur masing-masing konsentrasi larutan $\mathrm{AgNO}_{3} 2 \mathrm{mM} ; 1,5 \mathrm{mM} ; 1 \mathrm{mM}$; dan 0,5 mM dan air rebusan daun kluwak dengan perbandingan 40:1 kemudian diaduk, kemudian diukur dengan menggunakan spektrofotometer UV-Vis. 


\section{Sintesis Nanopartikel Perak}

Larutan $\mathrm{AgNO}_{3}$ 1,5 mM sebanyak $40 \mathrm{~mL}$ dicampur dengan $1 \mathrm{~mL}$ ekstrak daun kluwak kemudian campuran diaduk menggunakan magnetic stireer sampai terjadi perubahan warna menjadi kecoklatan. Setelah pencampuran pada waktu ke hari 1, hari 2, hari 3, hari 4, hari 7 hari 8 dan hari 9. Campuran kemudian disentrifugasi pada $1000 \mathrm{rpm}$ selama 20 menit lalu di keringkan dengan cara freeze drying kemudian dikarakterisasi PSA, XRD, SEM, FTIR dan uji antioksidan.

\section{Penentuan Aktivitas Antioksidan dengan Metode DPPH}

Uji aktivitas antioksidan dilakukan dengan metode efek perendaman terhadap radikal bebas N,N-diphenil-N-pikrilhydrazil (DPPH). Larutan induk 500 ppm dipipet sebanyak $0,1 \mathrm{~mL} ; 0,2 \mathrm{~mL} ; 0,4$ $\mathrm{mL} ; 0,8 \mathrm{~mL}$ dan 1,6 mL untuk membuat variasi konsentrasi berturut-turut $10 \mathrm{ppm} ; 20 \mathrm{ppm} ; 40 \mathrm{ppm}$; $80 \mathrm{ppm}$ dan $160 \mathrm{ppm}$. Masing-masing larutan dimasukkan ke dalam tabung reaksi, kemudian ditambahkan $1 \mathrm{~mL}$ larutan DPPH 0,4 mM. Volume dicukupkan sampai $5 \mathrm{~mL}$ dengan menggunakan metanol, kemudian diinkubasikan pada suhu ruang selama 30 menit di ruang gelap, selanjutnya serapannya diukur pada panjang gelombang maksimum ( $\lambda \max )$. Hasil penetapan antioksidan dibandingkan dengan vitamin C sebagai kontrol positif.

\section{HASIL DAN PEMBAHASAN}

\section{Sintesis Nanopartikel Perak}

\section{Optimasi Konsentrasi Larutan $\mathrm{AgNO}_{3}$}

Penentuan konsentrasi optimum dengan menggunakan larutan $\mathrm{AgNO}_{3}$ sebagai prekursor bertujuan untuk mengetahui perbandingan konsentrasi yang tepat dari larutan $\mathrm{AgNO}_{3}$ dan ekstrak daun kluwak dan kestabilan pada proses pembentukan nanopartikel perak yang akan dilakukan. Pengukuran absorbansi larutan dilakukan pada kisaran panjang gelombang 200-700 nm. Hasil pengukuran spektrofotometer UV-Vis menujukkan bahwa panjang gelombang dan absorbansi dari nanopartikel perak bertambah dengan bertambahnya waktu seperti yang terllihat pada Gambar1.

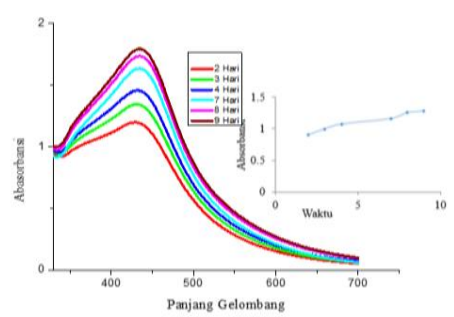

(a)

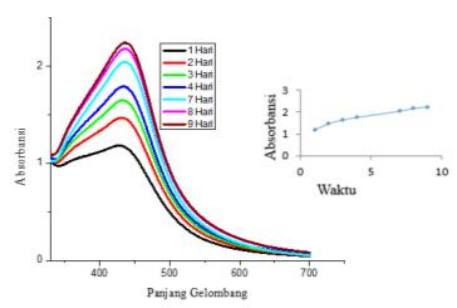

(c)

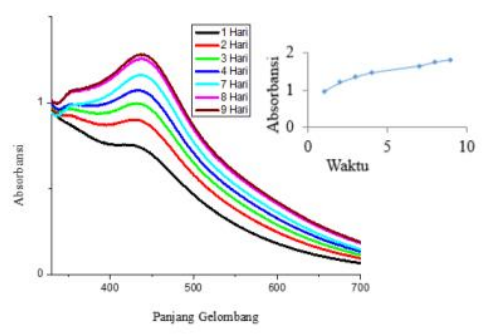

(b)

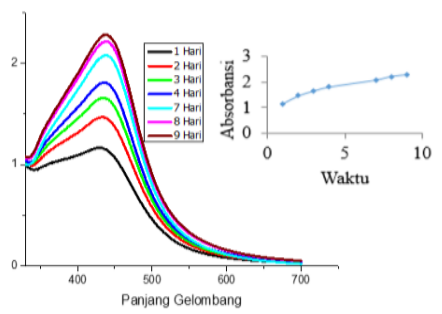

(d)

Gambar 1. Spektrum Serapan UV-Vis dari nanopartikel perak variasi konsentrasi $\mathrm{AgNO}_{3}$ (a) $0,5 \mathrm{mM}$, (b) $1 \mathrm{mM}$, (c) $1,5 \mathrm{mM}$ dan (d) $2 \mathrm{mM}$. 
Dari keempat variasi konsentrasi larutan $\mathrm{AgNO}_{3}$ menunjukkan bahwa nanopartikel perak cenderung lebih stabil pada konsentrasi $\mathrm{AgNO}_{3}$ 1,5 mM karena memiliki pangjang gelombang yang cukup kecil dan absorbansi yang besar jika dilihat dari data panjang gelombang maksimum serta memiliki absorbansi yang cukup besar jika dibandingkan dengan konsentrasi lainnya.

\section{Ukuran Nanopartikel Perak dengan Particle Size Analyzer}

Particle Size Analizer (PSA) digunakan untuk menentukan ukuran rata-rata nanopartikel perak. Data ukuran partikel yang diperoleh berupa tiga distribusi yaitu intensitas, nomor, dan volume, sehingga dapat menggambarkan keseluruhan kondisi sampel (Nikmatin dkk., 2011).

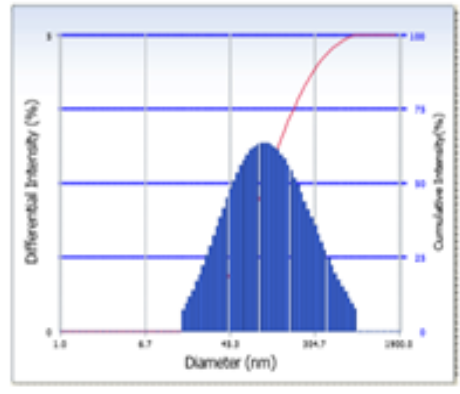

(a)

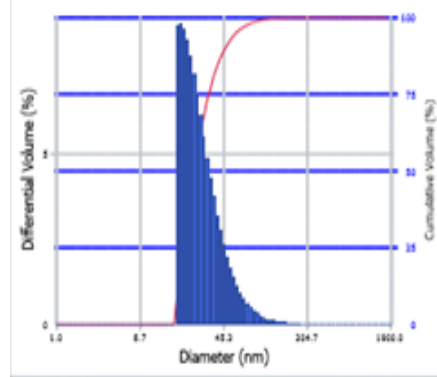

(b)

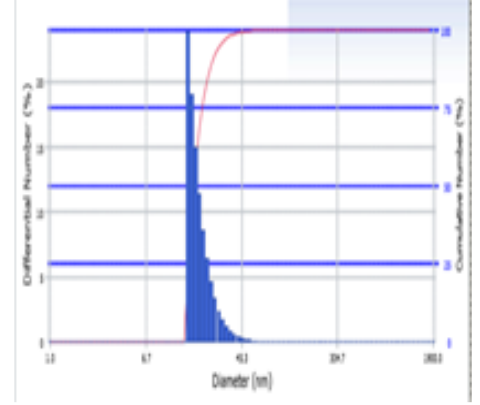

(c)

Gambar 2. Hasil analisis PSA nanopartikel perak, (a) dispersi ukuran dengan intensistas, (b) dispersi ukuran dengan nomor dan (c) dispersi ukuran dengan volume.

Hasil karakterisasi dengan menggunakan PSA menunjukkan secara keseluruhan rata-rata ukuran diameter nanopartikel perak yang telah berhasil disintesis (Gambar 6) yakni 93,2 nm. Analisis dengan PSA dilakukan di Laboratorium Fisika ITB (Institut Teknologi Bandung) dengan waktu pengiriman sampel sekitar 4-5 hari, sehingga diduga selama perjalanan terjadi guncangan yang menyebabkan ukuran partikel yang lebih besar karena kemungkinan telah mengalami aglomerasi.

\section{Karakterisasi menggunkan XRD}

Serbuk nanopartikel perak hasil sintesis selanjutnya dianalisis menggunakan XRD. Karakterisasi nanopartikel perak dengan menggunakan XRD dilakukan untuk mendukung pembuktian bahwa nanopartikel yang disintesis adalah murni nanopartikel perak.

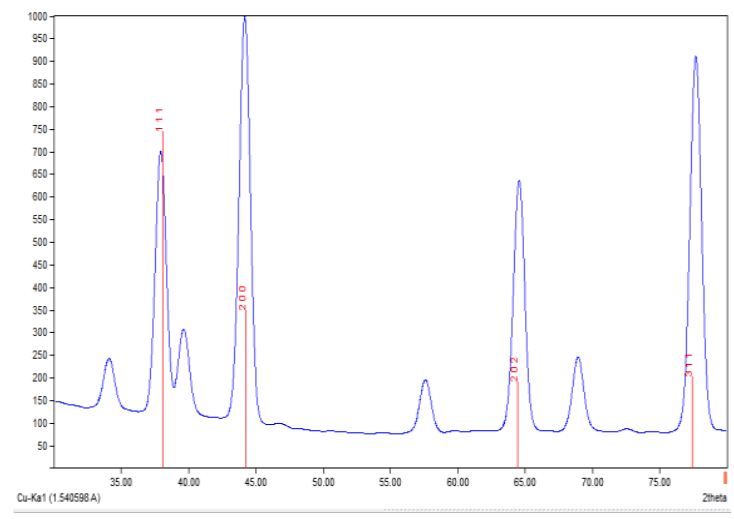

Gambar 3. Difraktogram XRD Nanopartikel Perak 
Hasil pengukuran XRD menunjukkan adanya ukuran nanopartikel perak. Perkiraan ukuran partikel perak dapat dihitung dari persamaan Debye-Scherer (Ahmad dkk., 2010). Difraktogram memperlihatkan adanya puncak selain puncak khas nanopartikel perak, hal ini menandakan bahwa nanopartikel perak yang dihasilkan belum murni nanopartikel perak atau masih banyak mengandug pengotor. Data difraktogram juga memberikan informasi distribusi ukuran butir nanopartikel perak. Dari perhitungan ukuran butir melalui XRD pada Tabel 4 terlihat bahwa distribusi ukuran naopartikel perak yang berhasil disintesis memiliki ukuran rata-rata yaitu 51,78 $\mathrm{nm}$.

\section{Karakterisasi FTIR}

Karakterisasi dengan menggunakan FTIR bertujuan untuk mengetahui gugus fungsi yang berperan sebagai bioreduktor. Spektrum FTIR ekstrak daun kluwak dan nanopartikel perak ditunjukkan pada Gambar 4.

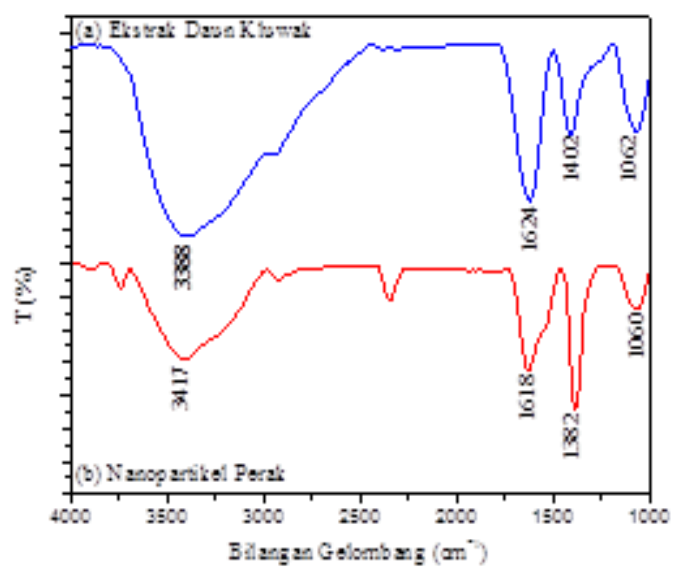

Gambar 4. Spektrum FTIR (a) Eksktrak Daun Kluwak dan (b) Nanopartikel Perak

Spektrum FTIR tersebut menunjukkan adanya kelompok fungsional yang berbeda-beda. Serapan pada bilangan gelombang $3388 \mathrm{~cm}^{-1}$ terlihat pada spektrum IR ekstrak daun kluwak. Serapan ini menunjukkan serapan khas dari gugus - $\mathrm{OH}$ dengan pita yang melebar dan kuat. Pita serapan yang tajam pada bilangan gelombang $1624 \mathrm{~cm}^{-1}$ menunjukkan serapan gugus $\mathrm{C}=\mathrm{O}$. Pita serapan pada bilangan gelombang $1062 \mathrm{~cm}^{-1}$ menunjukkan gugus $\mathrm{C}-\mathrm{O}$ dan pada bilangan gelombang $1402 \mathrm{~cm}^{-1}$ menunjukkan gugus $\mathrm{CH}_{2}$. Gambar 8 (b) menunjukkan spektrum IR setelah bioreduksi dengan menggunakan ekstrak daun kluwak. Spektrum tersebut memperlihatkan pergeseran bilangan gelombang gugus $-\mathrm{OH}$, gugus $\mathrm{C}=\mathrm{O}, \mathrm{CH}_{2}$ dan $\mathrm{C}-\mathrm{O}$ dengan bilangan gelombang berturut-turut menjadi $3417 \mathrm{~cm}^{-1}, 1618 \mathrm{~cm}^{-1}, 1382 \mathrm{~cm}^{-}$ ${ }^{1}$ dan $1060 \mathrm{~cm}^{-1}$. Pergeseran bilangan gelombang yang terjadi pada gugus $-\mathrm{OH}$ menunjukkan bahwa terjadi interaksi antara gugus - $\mathrm{OH}$ dengan Ag karena proses oksidasi reduksi. Perubahan intensitas pada setiap serapan gugus juga dapat menjadi indikasi proses bioreduksi yang terjadi (Nurafni dkk., 2017).

Pergeseran panjang gelombang terlihat jelas antara ekstrak air daun kluwak dan nanopartikel perak. Pergeseran bilangan gelombang menunjukkan bahwa terjadi interaksi antara gugus fungsi dengan nanopartikel. Berdasarkan pergeseran tersebut dapat disimpulkan kemungkinan gugus-gugus yang berperan dalam proses reduksi. Carillo-Lopez dkk (2014), menyatakan bahwa gugus -OH pada 
sampel dari senyawa seperti flavonoid, tanin saponin, dan alkaloid yang kemungkinan bertanggung jawab dalam reduksi ion perak.

\section{Karakterisasi SEM}

Analisis SEM bertujuan untuk menunjukkan morfologi partikel. Pembesaran gambar nanopartikel perak dilakukan pada skala 5.000x, 7500x, 10.000x, dan 15.000x. Sampel yang dianalisis dengan SEM adalah sampel nanopartikel pada Gambar 5.

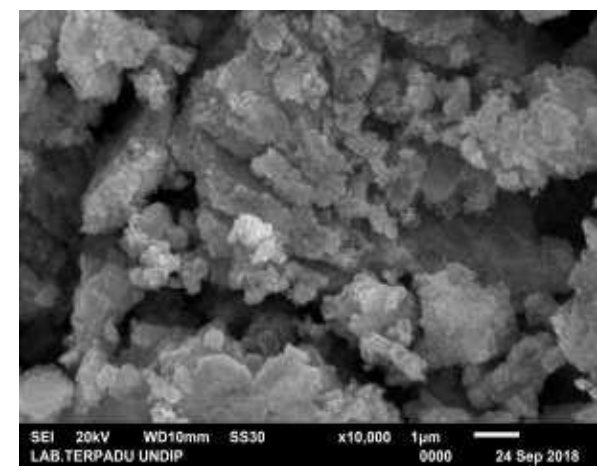

(a)

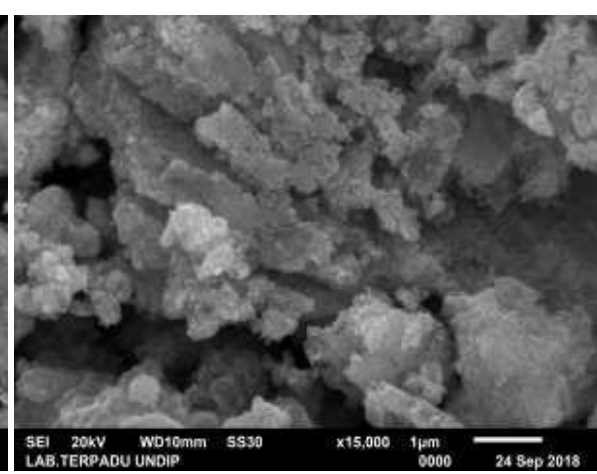

(b)

Gambar 5. Analisis morfologi nanopartikel perak menggunakan SEM (a). perbesaran 10.000x dan (b) $15.000 \mathrm{x}$

Gambar 5 memperlihatkan bentuk serta ukuran partikel nano yang diperoleh melalui hasil pengamatan menggunakan SEM. Morfologi dari nanopartikel perak memiliki peran penting dalam menentukan sifat nanopartikel seperti sifat optik, mekanik, konduktif dan toksisitas (Masakke dkk., 2015). Berdasarkan data SEM terlihat bahwa partikel nanoprtikel perak yang disintesis tidak seragam, bulat, ada yang berbentuk agak memanjang dan bergerigi pada setiap pinggir nanopartikel dengan ukuran yang cenderung bervariasi akibat dari agregasi partikel nano (Nurafni dkk., 2017).

\section{Uji Aktivitas Antioksidan}

Antioksidan merupakan zat yang mampu memperlambat atau mencegah proses oksidasi yang disebabkan oleh radikal bebas. Adapun metode yang digunakan untuk pengujian antioksidan pada sampel ekstrak daun kluwak dan nanopartikel perak adalah metode DPPH. Metode DPPH didasarkan pada kemampuan antioksidan untuk menghambat radikal bebas dengan mendonorkan atom hidrogen dan metode ini lebih sederhana, mudah, dan menggunakan sampel dalam jumlah yang sedikit dengan waktu yang singkat. Hasil pengukuran aktivitas antioksidan ekstrak daun kluwak dan nanopartikel perak dengan variasi konsentrasi dapat dilihat pada Tabel 1 . 
Tabel 1. Aktivitas antioksidan ekstrak daun kluwak dan NPAg

\begin{tabular}{cccc}
\hline & & \multicolumn{2}{c}{ \%Aktivitas antioksidan } \\
\cline { 3 - 4 } No & Konsentrasi (ppm) & $\begin{array}{c}\text { Ekstrak } \\
\text { Daun Kluwak }\end{array}$ & NPAg \\
\hline & & 1,08 & 4,10 \\
& 10 & 1,63 & 4,35 \\
3 & 20 & 2,71 & 4,87 \\
4 & 40 & 4,89 & 6,15 \\
5 & 80 & 10,05 & 8,71 \\
\hline
\end{tabular}

Aktivitas antioksidan terbesar terdapat pada ekstrak daun kluwak sebesar 10,05\% dengan konsentrasi $160 \mathrm{ppm}$ dan nanopartikel perak sebesar 8,71\% dengan konsentrasi $160 \mathrm{ppm}$. Sedangkan aktivitas antioksidan terkecil terdapat pada ekstrak daun kluwak sebesar 1,08\% dengan konsentrasi 10 ppm dan nanopartikel perak sebesar 4,10\% dengan konsentrasi 10 ppm. Pada konsentrasi yang tinggi senyawa yang terkandung akan semakin banyak dan menyebabkan semakin besar pula aktivitas antioksidannya. Adapun aktivitas antioksidan senyawa pembanding yaitu asam askorbat dapat terlihat pada Tabel 2.

Tabel 2. Nilai aktivitas antioksidan Asam Askorbat sebagai Pembanding

\begin{tabular}{ccc}
\hline \multirow{2}{*}{ No } & \multirow{2}{*}{ Konsentrasi (ppm) } & \%Aktivitas Antioksidan \\
\cline { 3 - 3 } & & Asam Askorbat \\
\hline 1 & 0,25 & 35,18 \\
2 & 0,5 & 37,65 \\
3 & 1 & 41,97 \\
4 & 2 & 53,08 \\
5 & 4 & 74,07 \\
\hline
\end{tabular}

Semakin tinggi konsentrasi sampel uji maka akan semakin besar pula peredamannya yang ditandai dengan terbentuknya warna kuning dikarenakan pada konsentrasi yang tinggi senyawa yang terkandung akan semakin banyak dan menyebabkan semakin besar pula aktivitas antioksidannya (Niche dkk.,2017). Asam askorbat yang digunakan sebagai pembanding atau kontrol positif memiliki aktivitas antioksidan jauh lebih besar dari ekstrak daun kluwak dan nanopartikel perak yaitu pada konsentrasi 4 ppm sebesar 74,07\%.

Berdasarkan data aktivitas antioksidan yang diperoleh maka dibuat persamaan regresi linear yang menyatakan hubungan antara konsentrasi larutan uji (x) dengan aktivitas antioksidan (y) sehingga diperoleh nilai IC50 yang merupakan konsentrasi larutan uji yang diperlukan untuk meredam DPPH sebesar 50\% (Molyneux, 2004). Nilai IC50 berbanding terbalik dengan aktivitas antioksidan dari ekstrak daun kluwak dan nanopartikel perak. Semakin besar aktivitas antioksidannya maka semakin kecil nilai IC50. 
Tabel 3. Nilai IC50 dari Ekstrak Daun Kluwak, Nanopartikel Perak dan Asam Askorbat

\begin{tabular}{ccc}
\hline No. & Larutan Uji & IC $_{\mathbf{5 0}}(\mathbf{p p m})$ \\
\hline 1 & Ekstrak daun Kluwak & 831,33 \\
2 & Nanopartikel perak & 1493,09 \\
3 & Asam Askorbat & 1,70 \\
\hline
\end{tabular}

Berdasarkan Tabel 7 nilai IC $_{50}$ dari ekstrak daun kluwak sebesar 831,33 sedangkan untuk nanopartikel perak diperoleh sebesar 1493,09 dan sebagai pembanding asam askorbat mempunyai aktivitas antioksidan sangat kuat dengan nilai IC50 sebesar 1,70 ppm. Menurut (Molyneux, 2004), suatu senyawa dikatakan sebagai antioksidan yang sangat kuat apabila nilai IC50 kurang dari 50 ppm, antioksidan yang kuat apabila nilai IC50 antara 50-100 ppm, antioksidan sedang apabila nilai IC50 antara 100-150 ppm, antioksidan lemah apabila nilai IC50 antara 150-200 ppm dan antioksidan sangat lemah jika diatas 200 ppm. Perbedaan nilai $\mathrm{IC}_{50}$ ini dapat disebabkan oleh jumlah antioksidan yang terkandung di dalam ekstrak. Metode peredaman radikal bebas DPPH didasarkan pada reduksi dari larutan metanol radikal bebas DPPH yang berwarna oleh penghambatan radikal bebas (Tristantini dkk., 2016). Efek antioksidan dari DPPH yaitu senyawa ini bereaksi dengan senyawa antioksidan melalui pengambilan atom hidrogen dari senyawa antioksidan untuk mendapatkan pasangan elektron. Sehingga mengubah warna dari ungu menjadi kuning yang diukur pada panjang gelombang $515 \mathrm{~nm}$. Reduksi dari tanaman disebabkan oleh transfer elektron atau hidrogen dari antioksidan tergantung pada struktur antioksidan yang berbeda (Tapa dkk., 2016).

\section{KESIMPULAN}

Berdasarkan hasil penelitian dapat disimpulkan bahwa daun kluwak Pangium edule Reinw dapat digunakan sebagai bioreduktor dalam sintesis nanopartikel perak. Ukuran nanopartikel dari hasil karakterisasi menggunakan PSA adalah 93,2 nm. Ukuran nanopartikel perak yang dihasilkan berdasarkan rumus Debye-Scherer adalah $51,78 \mathrm{~nm}$. Nanopartikel perak mempunyai aktivitas antioksidan sangat lemah dengan nilai IC50 sebesar 1493,09 ppm dan ekstrak daun kluwak mempunyai aktivitas antioksidan sangat lemah dengan nilai IC50 sebesar 831,33 ppm.

\section{DAFTAR PUSTAKA}

Ariyanta, H.A., 2014. Preparasi Nanopartikel Perak Dengan Metode Reduksi Dan Aplikasinya Sebagai Antibakteri Penyebab Luka Infeksi. Jurnal MKMI:36-42.

Asri, M., 2015. Karakterisasi Nanopartikel Emas dan Aplikasinya sebagai Sensor Kadar Gula Darah. Tesis tidak diterbitkan. Jurusan Kimia FMIPA Universitas Hasanuddin, Makassar.

Abdel-Aziz, M.S., Shaheen, M.S., Aziza A., El-Nekeety, A.A., dan Abdel-Wahhab, M.A., 2013. Antioxidant And Antibacterial Activity Of Silver Nanoparticles Biosynthesized Using Chenopodium Murale Leaf Extract. Journal of Saudi Chemical Society: 1-8.

Bharathi, D., Josebin, M.D., Vasantharaj, S., dan Bhuvaneshwari, V., 2018, Biosynthesis Of Silver Nanoparticles Using Stem Bark Extracts Of Diospyros Montana And Their Antioxidant 
And Antibacterial Activities. Journal of Nanostructure in Chemistry: 1-10.

Isaac, R.S., Sakthivel, G., dan Murthy, C., 2013. Green Synthesis and Characterization of Silver Nanoparticles Using Banana Peel Extract and Their Antimicrobial Activity Againts Representavi Microorganisme. Journal of Radiation Reasearch and Applied Sciences 8: 265-275.

Matutu, J.M., Maming, Taba, P., 2016, Sintesis Nanopartikel Perak Dengan Metode Reduksi Menggunakan Buah Merah (Pandanus Conoideus) Sebagai Bioreduktor, Skripsi Diterbitkan, Jurusan Kimia, Fakultas Matematika dan Ilmu Pengetahuan Alam, Universitas Hasanuddin, Makassar.

Nagarajan, R., dan Hatton, T.A., 2008. Nanoparticles Synthesis Stabilization Passivation and Functionalization, Am. Chem. SOC, Oxford University Press, London.

Rumengan, A.P., Dan Mantiri, D.A., 2015. Uji Aktivitas Antioksidan Ekstrak Alga Dictyosphaeria cavernosa dari Perairan Teluk Manado, Jurnal LPPM Bidang Sains dan Teknologi, 2(2): 71-77.

Thomas, B., Prasad, A.A., dan Vithiya, S.M., 2018. Evaluation Of Antioxidant, Antibacterial And Photo Catalytic Effect Of Silver Nanoparticles From Methanolic Extract Of Coleus Vettiveroids - An Endemic Species. Journal Nanostruct 8(2): 179-190.

Wahyudin, T., Sugiyana, D., dan Helmy, Q., 2011. Sintesis Nanopartikel Perak Dan Uji Aktivitasnya Terhadap Bakteri E. Coli Dan S. Aureus, Balai Besar Tekstil, 21(6): 55-60.

Winarsi, H., 2007. Antioksidan Alami dan Radikal Bebas, Penerbit Kanisius, Yogyakarta. 